\title{
Editorial
}

\section{One regulator for all?}

International Journal of Disclosure and Governance (2007) 4, 1-2.

doi:10.1057/palgrave.jdg.2050048

In the United Kingdom, the Financial Services Authority is responsible for all forms of financial regulation including banking, commodities, securities, insurance and derivatives. While securities regulation, for instance, may not be as fully developed in the UK or as fully enforced as it is in the US, the approach of UK regulation - even though different staff are responsible for each form of enterprise - is sharing and pooling of information. This is sorely lacking in the US approach where there are at least three different banking regulators, the Securities and Exchange Commission (SEC) to regulate securities, the Commodities Futures Trading Commission (CFTC) to regulate commodies and futures, state regulators to regulate insurance and no one to regulate private equity or hedge funds.

A recent Supreme Court decision has denied the SEC the authority to regulate hedge funds, and private equity remains beyond the pale of regulation, except to the extent that securities laws have been violated by these forms of business. In 2003, the SEC proposed voluntary registration of hedge funds and abundant disclosure of capital structure. The extent of hedge fund and private equity activity creates potential disequilibrium in financial markets.

The last round of financial scandals in the US was rife with issues that jumped regulatory barriers: off-balance sheet accounting issues of an energy company, Enron, which was operating as a financial conglomerate, banks' conflicting roles as investment banks and lending institutions in Enron and Worldcom, insurance companies offering finite insurance enabling other companies to engage in fraudulent accounting.
A single regulator could have sorted through these issues more quickly and efficiently and might have even arrested fraudulent practices as they occurred rather than cleaning up the aftermath.

The number of buyouts by private equity firms surged to 2,677 in 2005 with a value of about $\$ 326$ bn. The risks posed by private equity include potential conflicts of interest and market abuse. The Department of Justice is looking into 'club deals'. Another risk is the level of debt companies take on. Only 30 per cent of syndicated debt will be held by banks, but asset managers and hedge funds that may be highly leveraged now hold considerable amounts of debt.

All estimates of this kind, however, are of necessity vague since neither private equity nor hedge funds are directly regulated. The existence of systemic risk cannot be calculated given the extent of activity by unregulated entities. It is also not clear that Basel II capital adequacy standards really capture the risk posed by cascading failures by hedge funds and private equity groups. Consider how the failure of one hedge fund's LTCM (Long-Term Capital Management) might unwind banking positions in such a way as to cause systemic failure. What havoc would cascading failures of hedge funds and private equity firms cause in world financial markets?

Regulating hedge funds and private equity may be part of the solution. But a single regulator that regulates all forms of public financial entities and consequently has access to meaningful information about intermarket risk, between securities markets and futures markets, between hedge 
fund markets and banking markets, for instance, would provide the most efficient form of regulation. Form regulation now utilised is a vestige of the mid-20th century when banking and investment banking were entirely separate and only public companies could raise substantial funds. The current regulatory fragmentary approach poses unnecessary risks to the safety and soundness of the financial system.

Mr John Friedland

Editor 